Lindahl, M. G. \& Linder, C. (2013). Students' ontological security and agency in science education - an example from reasoning about the use of gene technology. International

\title{
Students' ontological security and the agency in science education - an example from reasoning about the use of gene technology
}

\author{
Mats Gunnar Lindahl and Cedric Linder
}

\begin{abstract}
This paper reports on a study of how students' reasoning about socioscientific issues is framed by three dynamics: societal structures, agency and how trust and security issues are handled. Examples from gene technology were used as the forum for interviews with 13 Swedish high-school students (year 11, age 17-18). A grid based on modalities from the societal structures described by Giddens was used to structure the analysis. The results illustrate how the participating students used both modalities for 'Legitimation' and 'Domination' to justify positions that accept or reject new technology. The analysis also showed how norms and knowledge can be used to justify opposing positions in relation to building trust in science and technology, or in democratic decisions expected to favour personal norms. Here, students accepted or rejected the authority of experts based on perceptions of the knowledge base that the authority was seen to be anchored in. Difficulty in discerning between material risks (reduced safety) and immaterial risks (loss of norms) was also found. These outcomes are used to draw attention to the educational challenges associated with students' using knowledge claims (Domination) to support norms (Legitimation) and how this is related to the development of a sense of agency in terms of sharing norms with experts or with laymen.
\end{abstract}

\section{Introduction}

A good example of an educational context where understanding of the development of agency and reasoning is important is when discussions about societal use of gene technology take place. This article uses such a context to look at the development of agency in relation to societal structures when students handle trust and security issues.

New technologies such as gene technology should be areas for on-going educational debates that explore the benefits, potential risks, norms and values connected to the societal changes that such technologies bring to society. These debates have been characterized in terms of emergent anxiety and a loss of a sense of security as society is experienced as being more fragmented and difficult to understand (Giddens, 1984, 1990). Members of society are confronted with such issues through a variety of media, presented using the perspectives of different stakeholders (Gaskell, 1992). Furthermore, in societal discussions concerning technology, 'originators and instigators' try to portray themselves as trustworthy by making truth-sounding claims, which laymen usually have tremendous difficulties scrutinizing (Kolstø, 2001b; Kolstø et al., 2006). 
Science education can play a role in bridging the gap between experts and laymen by creating a sense of trust in experts, using convincing information, or by providing tools for a dialogue where experiences, knowledge, and trust can be exchanged. At present, education is expected to afford future members of society the ability to participate in democratic discussions about societal development that is likely to embrace new scientific knowledge and new technologies. However, students come to class already submerged in a variety of views on the use of expert knowledge and new technology (Bauer, 2005; Nelkin, 2001). Hence, their attempts to make meaning of information, and negotiations about meanings, come face-to-face with conflicts relating to values, norms and concerns about societal practice and to expectations about participation in the reconstitution of society. At the same time, despite there having been some valuable progress here, modern science education typically continues to provide little means for students to engage in discussions about conflicts they have experienced and to develop their roles as participants in the reproduction and transformation of society (Kolstø, 2001a; Zeidler \& Sadler, 2008). Much of science education still focuses on reproduction of society, giving students little, if any, competency for such active participation (Brennan, 2008; Kalantzis, 2006; Szkudlarek, 2007). To develop a science education that embraces the idea that students should share and construct knowledge alongside values and norms that facilitate active participation in societal development with a sense of agency, more knowledge is needed about students' reasoning concerning socioscientific issues and how they use and appear to understand the structures in the societal system.

In this article, the term 'norms' is used to characterize moral or non-moral societal rules (Hechter \& Opp, 2001). The term 'values' is used to characterize expressions of human requirements concerning needs and social group demands (cf. Schwartz \& Bilsky, 1987) that can be used as justifications or explanations for norms.

\section{Focusing knowledge for a knowledge society}

Science education has historically focused on disciplinary content knowledge, presenting science as the 'objective' truth. For example, the Public Understanding of Science (PUS) movement aimed at establishing an extensive support base for technological development in society by informing the 'ignorant' public (Irwin \& Wynne, 1996) of the beneficial benevolence of technical development. In this spirit, the use of surveys to gather information about the public attitude to science and technology was initiated (Irwin, 2001). The use of surveys and interviews was then given an aura of 'consulting the public' (Levitt, 2003). At the same time, surveys have shown that views held by adults and students are similar and education that symbolizes a high degree of knowledge tends to induce positive attitudes towards societal practices using new technologies (Dawson, 2007; Gunter, Kinderlerer, \& Beyleveld, 1998). The influence of knowledge is further seen from studies that show that a low degree of knowledge coincides with a high degree of scepticism and fear (Heijs, Midden, \& Drabbe, 1993; Kelley, 1995). In the setting of this article, the association between a high degree of knowledge and positive attitudes to biotechnology seem to depend heavily on trust (Christoph, Bruhn, \& Roosen, 
2008; Knight, 2007). Thus, knowledge can be seen to have a positive effect on laymen's attitudes, as long as there is trust in authorities.

The development of science-technology-society (STS), which started some 30 years ago, introduced social and technological contexts to which students could relate (Fensham, 1988; Gaskell, 1982; Solomon, 1993). STS embraced new attitudes, inviting students to engage in scientific/technological issues using their experiences from everyday life and to draw on 'subjective views' such as ethical, social and political opinions in the discussions. This way, uncertainties about future societal change could be admitted under the guise of norms and potential risks. However, the extended discourse did not integrate subjective views, but merely acknowledged them. STS still focused on content knowledge and thus directly supported the notion of a knowledge society, a situation considered to be a challenge to many students' worldviews (Costa, 1995; Phelan, Davidson, \& Cao, 1991). It has been suggested that the resulting conflicts could be resolved by 'collateral learning' that includes the addition of a parallel worldview, a mix between personal and scientific worldviews, or a worldview somewhat changed with the help of scientific knowledge (Aikenhead \& Jegede, 1999). Changing of worldviews is considered an active learning process, where students modify their one worldview instead of having multiple immiscible worldviews (Cobern, 1996).

\section{Integrating and discussing scientific knowledge with subjective views}

STS took a step further with the introduction of socio-scientific issues (SSIs), which focused on students' decisions about controversial issues making use of morals and values, as well as scientific knowledge (Driver, Newton, \& Osborne, 2000; Ratcliffe, 1996; Solomon, 1992; Zeidler, Lederman, \& Taylor, 1992). The introduction of SSI in science education encouraged new research into knowledge about students' reasoning and how to promote learning by using SSI (Fowler, Zeidler, \& Sadler, 2009; Sadler \& Fowler, 2006; Sadler \& Zeidler, 2004, 2005a; Tal \& Kedmi, 2006; Zeidler \& Keefer, 2003; Zeidler, Sadler, Simmons, \& Howes, 2005; Zohar \& Nemet, 2002). SSI provided the means for the development of a capability to participate in democratic processes concerning societal use of science and technology. Engaging in SSI would provide students with both scientific content knowledge and the opportunity to develop reasoning capabilities. Successful SSI called for a scaffolding of students' discussions to allow for a multitude of perspectives and solutions to problems (Aikenhead, 2006; Klosterman \& Sadler, 2010; Sadler, 2004; Sadler \& Zeidler, 2005a; Taylor, Lee, \& Tal, 2006; Zeidler \& Sadler, 2008). In such a scenario, students' informal reasoning patterns need to be met respectfully in a way that facilitates open and constructive discussion for the understanding of emotional, moral and rational reasoning (Sadler \& Zeidler, 2005b; Zeidler \& Sadler, 2008).

SSIs are open-ended, ill-structured, debatable problems, which are susceptible to multiple perspectives and solutions. They provide opportunities for individuals to engage in informal reasoning as they try to negotiate possible solutions to the problems encountered. Doing so, they gain experiences that are believed to support future participation in democratic decisions about SSIs. The ability to participate in democratic discussion has been modelled 
as part of scientific literacy, and a few studies have shown the advantage of using SSI for that purpose (Driver et al., 2000; Kolstø, 2000, 2001a). Here, the issue is to provide education for development of analytical thinking to be able to evaluate claims related to science and its use in societal practice. The idea that science education should help students to develop a critical stance towards knowledge claims, as well as an ability to participate in discussions with logical arguments is congruent with a modern definition of scientific literacy (Aikenhead, 2007; Norris \& Phillips, 2003; Roberts, 2008; Zeidler \& Sadler, 2010).

\section{Development and changing role of science education}

The role of science education in society has shifted over time. The changes include norms and how these are conveyed to students, the societal use of science and how to participate in societal discussions about science and technology. The role of education in general has been described as reproducing societal practice (Giddens, 1984) and propagating societal development (Giddens, 1984; McWilliam \& Lee, 2006) by constructing and supporting a knowledge society (Brennan, 2008; Szkudlarek, 2007). Levinson (2010) provides four frameworks for describing different ways by which the role of science education for democratic participation is described. For example, two of Levinsons categories, 'Deficit' and 'Deliberative democracy' fit well with the notion of a knowledge society. In a knowledge society, most members of society still end up having to rely on experts in a way that reduces their direct participation in societal development. Brennan (2008) suggests that the role of education also could be to transform society, thus constructing a critical society. Critical society anticipates more direct participation in democratic processes since laymen are empowered by knowledge and negotiation skills to engage in discussions with experts about issues related to societal transformation (Kalantzis, 2006). The notion of critical society corresponds to the frameworks Levinson (2010) calls 'Science education as praxis' and 'Dissent and conflict'.

\section{Towards science education for a critical society}

The change from a science education for a 'knowledge society' towards a science education for a 'critical society' can be tracked through a changing and diverging scientific literacy concept and the development of new educational traditions (Aikenhead, 2007; Norris \& Phillips, 2003; Roberts, 2008; Zeidler \& Sadler, 2010). The concept of scientific literacy can be divided into derived and fundamental senses of scientific literacy (Norris \& Phillips, 2003). The derived form is content knowledge in the form of disconnected facts and theories, whereas the fundamental form of scientific literacy can be described as understanding how relationships between facts and theories can be made to produce meaningful knowledge. Here, Roberts (2008) describes how scientific literacy has developed and changed from, what he calls, scientific literacy vision I to scientific literacy vision II; the former being focused on knowledge and scientific goals, whereas the latter also brings in understanding in a way that facilitates some ability to participate in the making of democratic decisions regarding science and technology. Aikenhead (2007) has, in addition, proposed scientific literacy III that is a global variant of vision II, taking into consideration not only western but all cultures on our planet.

Zeidler and Sadler (2010) recently proposed 'functional' scientific literacy as a development of scientific literacy vision II. 'Functional' scientific literacy broadens the concept of scientific literacy to be more supportive of science education for a 'critical society'. This is achieved by 
including students' development of reflective reasoning and morals in line with the quest to become active citizens personally engaged in the decisions affecting their community, i.e. to have a sense of agency. By promoting not only scientific knowledge, but also students' development of morals and reasoning skills, with 'functional' scientific literacy as a goal, science education has the potential to enable students to become active citizens who can reconfigure the balance between experts and novices, as called for by Kalantzis (2006). Such rebalancing, whereby citizens gain a sense of agency for the transformation of society, is important for power relations and would impact on the view of expert knowledge and the role of expert systems (Giddens, 1984, 1990). However, more knowledge about how students use and understand the structures in the societal system, as they reason about SSIs, is needed to support the development of science education in that direction.

\section{Theoretical framework}

Previous research on attitudes to science and technology and views on SSIs has focused on students as individuals with a range of different views. They are seen as students who are not yet intrinsically part of society in the sense that they lack mature ideas about the kinds of societal development needed for participation in democratic decisions such as elections and referendums. The focus has been on the here-and-now learning of knowledge, developing morals and acquiring communicatory skills aimed for the participating in a future society as adults. Giddens' writing about the societal system refers to relations between people. These relations are organized and reproduced in social practices that are subject to change. The transformation of social relations is possible through acts of the individual agents that reproduce a societal structure. Such a societal structure consists of the rules and resources belonging to the system, for example, laws, moral codes, tradition, established practices, authorities and institutions. These allow or constrain individual agents to participate in the transformation of social relations. Human agents reinforce or transform social relations and societal practice, thus slowly changing the structure of the system to provide new conditions for societal relations. This iterative process is known as 'structuration' (Giddens, 1984). In our study, Giddens' structuration theory is chosen for the purpose of relating the students' views to on-going societal discussions and of viewing the students as members of society with an emergent interest in participating in a developing society.

Social systems have three types of structures, each of which has modalities: 'Signification', which can be described as the interpretive schemes and discursive practices used by agents, such as, for example, 'gene technology is a threat to society'; 'Domination', which describes how resources are controlled and how power is used, including, for example, the use of knowledge claims; and, 'Legitimation', which is the process of reinforcement of moral rules and other norms. These three structures constrain societal transformation potentials that more or less reinforce societal practice. If the result is a reproduction of societal practice, members of society can maintain their sense of security (Giddens, 1984, 1990). However, expert knowledge, such as scientific knowledge, can have a transformative power in society (Giddens, 1990). It emanates from a practice that is disembedded, i.e. lifted out from social relations and norms embedded in local contexts. Whereas in embedded practice, social relations are present and the context is familiar. The familiar is as important for students as for any member of society because one's sense of security depends on how understandable changes in the environment are over time. The sense of security, or 'ontological security' as Giddens prefers to call it, is a sense of reliability on people and things in the environment, and an 
understanding of the life-world. Routines, routinized practice and traditions provide ontological security by tying together activities at different points of time, thus reducing the experience of 'fragmented existence' (Giddens, 1990). This is caused by societal changes due to, for example, new technology. The resulting loss of ontological security can be counteracted by the 'routinization' of new practices and by the re-embedding of new knowledge and practices into familiar contexts.

The ability to monitor and understand human action in society can produce a sense of security, which in turn can affect intended, and as well as unintended actions for the reproduction or the transformation of societal practice. Subsequent activity aimed at understanding and governing these intended actions can then induce a sense of agency. The ability to judge the effectiveness of practices for the achievement of desirable objectives can also promote a sense of agency through the attainment of confidence in the ability of situated human action to obtain desirable outcomes. Although, when it comes to expert knowledge, for example, in an area such as gene technology, monitoring is usually not possible for laymen. However, scientific literacy has the potential to reduce this problem. An anticipated risk of societal transformation due to, for example, development of new technology may severely affect a sense of security, but trust can 're-install' a lost sense of security. Personal face-to-face encounters with experts can induce trust, which in turn can counteract the loss of ontological security. However, such encounters are constrained by the structures of a social system. For example, an inability to monitor an activity in societal practice - such as initiating genetic screening of citizens-can reduce a person's sense of security and accentuate the feelings of living with potential risks.

Risk and trust are intertwined in the sense that, for example, a dialogue between experts and laymen can, by inducing trust, reduce the anxiety connected to the anticipated risk. Public information and science education have roles to play in enabling personal and public decisions concerning risk and trust. Thus, science education can be seen as having the role of bridging the gap between embedded and disembedded practices in two different ways. First, by inducing trust by conferring knowledge, norms and values, and secondly, by providing possibilities for constructing knowledge and the understanding of personal values and norms, as well as the reasoning skills that empowers students to engage in negotiation of social practice relating to science and technology (cf. SSIs). The development of knowledge-enabling reflection on power relations, societal norms and scientific discourse supports agency, which may lead to re-balancing between experts and novices in society. Reflexive participation in societal practice describes a more profound form of agency that allows reflexive monitoring of action and participation in transformation of societal practice. Furthermore, meaning-making through a variety of interpretive schemes resembles agency in such a way that it enables dialogues with implications for future societal transformation between laymen and experts.

\section{Research questions}

Much knowledge about students' reasoning concerning SSIs has been accumulated to date. However, little is known about students' reasoning concerning SSIs in relation to their understanding of the interplay between societal structures. Such knowledge has implications for the organization of science education with the potential to enable students to further develop knowledge, morals and the ability to actively participate in societal development with a sense of agency. As students encounter conflicts through SSI they should be provided with opportunities to develop their roles as participants in the reproduction and transformation of 
society. Knowledge about the interplay between societal structures and their modalities can facilitate such a development as well as students' use of knowledge and skills in societal discussions.

From this point of view, the aim of this article is about increasing knowledge about students' reasoning concerning SSI that is framed by their notion of societal structures. To do this, students' reasoning about gene technology is used as an example of technologies that can induce an anticipation of transformation of societal practice. A focus emerges on the discernment of how students draw on societal structures, and how they handle trust and security issues in their reasoning about societal use of gene technology. From here, the following research questions are constituted:

1. What is the nature of the justifications that students provide for their significations of the societal use of scientific knowledgeand technology?

2. Howdo students deal with loss of ontological security?

3. From an agency perspective, how do students relate to social systems and personal agency when reasoning about societal decisions?

\section{Methodology}

\section{Participants}

The 13 participants (average age, 17.9 years) were high-school students (year 11 of a 12-year educational system) from two classes. These classes came from different schools in a small city (50,000 inhabitants) in the south of Sweden. These were a subset of students who had been involved in a socio-science study before (Lindahl, 2009, 2010), which greatly helped facilitate arranging their participation in this research context. Nine students (seven boys and two girls) were studying natural sciences and four (girls) were studying social sciences. We chose these classrooms because there was nothing discernibly distinct about their educational environment, particularly in terms of content or the experienced approach to teaching.

At the time of the data collection, $3-5$ weeks had passed since the participating students had completed an introductory course in genetics. Each of the genetics courses were given by separate teachers and some aspects of the content differed between them. The natural science students had a combined biology-chemistry course, where DNA as a chemical was studied in parallel with genetics. Furthermore, the natural science students were able to do laboratory work that consisted of a simple Restriction Fragment Length Polymorphism analysis intended to show how dissimilar genes could be detected. Apart from that the genetic courses had similar content dealing with Mendelian genetics, genetic diseases, DNA replication, transcription, protein synthesis and gene technology. Neither of the teachers discussed issues related to the research questions. Both classes had one group discussion related to genetic diseases and ethics where the students were divided in small groups (four to five students in each group).

\section{Data collection}

The study started after the students were given questions that were to be answered privately at home. The written material was interpreted and this was captured in the form of a mind map that we used to help frame semi-structured interviews. The purpose was to create a rich 
simulated recall (Calderhead, 1981) environment that could establish a good interactive environment for the planned interviews. As such, an integral part of the interviews was an interactive working with the students to refine the mind maps (when the students felt it was necessary) in order to better capture their thoughts, reflections and positioning. However, these mind maps themselves did not form part of the data set that we used for the analysis reported on in this article. The data used consisted entirely of the verbatim transcripts of the interviews. Occasionally, the mind maps were referred to help the analysis process in keeping themes together that helped track the students' personal views.

The semi-structured interview protocol had the following format: An exploration of how the students valued and felt about the use of knowledge with regard to examples A-E below? (These examples weretaken one at a time):

4. Describe the pros and cons you can foresee for each example.

5. Describe if you thinkit is right or wrong and explain your stance.

6. Describehowyou feel about the described examples:

7. Prenatal diagnostics to find and to eliminate genetic disease.

8. Transgenic pigs as organ donors for humans.

9. Psychopharmacological drugs and other synthesized drugs for the well-being of humans.

10. Gene technology can be used to produce natural substances for medical use.

11. Gene therapy, using virus or genetically modified stem cells, for treatment of different diseases for well-being and to reduce theuse of drugs.

Each student was interviewed for approximately $30 \mathrm{~min}$. At the beginning of the interview, the student was reminded of the ethical grounding for the research, in particular, the guaranteed anonymity for any descriptions that would be used as data, and that interviewer-interviewee co-operation would be an integral part of reaching an understanding of the meaning of the arguments presented.

The interview had a strong discussion-grounding where the students were asked to expand on what they had earlier written and to deepen their arguments. At the end of the interview, the students were asked whether the mind map that they and the interviewer had looked at during the interview represented an 'accurate' outline of their thinking, knowledge, and arguments. These interviews were recorded and transcribed verbatim.

Since all students agreed on the 'accuracy' of the resulting mind maps, we interpreted the data as reliably representing the students' views. As students were interviewed, their reasoning was explored in order to deepen their understanding and to probe for more viewpoints and explanations. The student's discussions were respected without any judgmental attitude, but rather with a genuine interest in their thinking, reflections and positioning and how it might be understood. All students discussed the topics eagerly and in a highly engaging way. Although we created a respectful environment, we are aware that the students could have, at times, experienced negative power relations. Thus, the interview data cannot be regarded as providing a full description of the views the participating students had at the time of the data collection. So we looked for similarities with other studies to strengthen the relevance and the validity of the data that we present. 


\section{Data analysis}

The analysis was done by collating pieces of description that well captured the essence of the students' arguments for or against the use of new technology, and regarding decisions about the use of new technology in society. These descriptions were sorted and categorized by content and lines of arguments. Categorization of students' views on the use of and decisions about gene technology was done following themes that fit into the structural concepts describing 'societal structure' (Giddens, 1984). Hence, the structures Signification, Legitimation, and Domination and their modalities, as they appeared to be manifested in students reasoning, were used to create a grid for the analysis (Table 1). The modalities of each structure are part of the theory of structuration (Giddens, 1984), but for the purpose of our analysis they are grouped in categories.

Using the grid shown in Table 1, justifications for students Significations were sought in the modalities of the structures Legitimation and Domination. The modalities that the students drew on indicated which societal structure was relevant to their interpretative scheme and for human actions in society.

Democracy and laws are here used together as one single modality of the structure Legitimation since they are highly interconnected in a representative democracy such as Sweden. When students refer to impersonal rules, moral or not, which are not laws, the analytic interpretation is in terms of drawing on norms. Furthermore, the analytic interpretation also holds that students draw on knowledge claims when they use scientific knowledge as a given fact to justify their signification of technology. There are two criteria for such scientific knowledge claims here: first, it has to be possible to interpret them as emanating from expert knowledge, i.e. from disembedded practice; and, secondly, such scientific knowledge claims have to be used by students as a non-disputable fact.

Ontological security cannot be assessed by the methods we used in our study, so they are hypothetically inferred as a theoretical entity supported by Giddens' structuration theory (Giddens, 1984).

Students' expression of confidence in the social system to regulate or stimulate development and use of expert knowledge to maintain/reach desirable outcomes is interpreted as an indication of students' agency. Students' descriptions of actions that they believe can lead to reproduction or transformation of society are interpreted as expressions of their reflexive monitoring. Their expressed confidence or their lack of confidence in their ability to affect or participate in actions leading to their desirable outcome is interpreted as an expression of agency. The analytic descriptions show a variety of students' ideas and arguments. There were conflicts between students as well as, occasionally, within their own line of arguments. However, the conflicts regarding use of and decisions about gene technology that were expressed by any single student were typically related to context. Subsequently, the data presented are valid for more or less-specific contexts regarding societaluse of new technology. 
Structures

\begin{tabular}{|c|c|c|c|}
\hline & Signification & Legitimation & Domination \\
\hline Modalities & Interpretative schemes & $\begin{array}{l}\text { Norms } \\
\text { Traditions } \\
\text { Democracy and laws }\end{array}$ & $\begin{array}{l}\text { Knowledge claims } \\
\text { Authorities }\end{array}$ \\
\hline
\end{tabular}

\section{Results}

In this section, we first describe what modalities of societal structures the students used when they justified their arguments in support for either a transformation or a reproduction of society through expert knowledge. The analysis dealing with the students' justification of anticipated social transformation, using a particular modality of social structure is followed by students' justification of the prevention of social transformation using the same modality. Starting with norms followed by traditions, modalities of the structure Legitimation are followed by the modalities of the structure Domination: first knowledge claims, then authorities.

The presentation of the analysis then moves on to dealing with the students' signification of decisions about the use of technology, either as enabling or as limiting human action in society. The storyline starts with the students' use of the modalities of Legitimation, norms, democracy and laws, and ends with the students' drawing on authorities, a modality of Domination.

\section{Signifying gene technology as a threat to or as a development of societal practice}

In this section, we illustrate how the students conceive of gene technology as a threat and convey their desire to prevent transformation of society. This is in stark contrast to students who regard gene technology as a promise of a desirable development of social practice. In this process, they were found to draw on modalities of Legitimation (norms and traditions) and Domination (knowledge claims and authorities). The students' reasoning points to attempts to find trust in basic principles or experts, but also to maintain their lack of trust and to bring attention to risks and undesired outcomes. In contrast to students who welcome biotechnology, the students who hesitate to incorporate gene technology in societal practice do not seem to find trust in persons or principles of expert systems.

\section{Signification by drawing on modalities of legitimation.}

When students signify biotechnology as an opportunity to develop or as a threat to societal practice, they refer to norms and traditions. Future actions for the 'good of humans' are supported by norms. However, prevention of actions that threaten values representing the good, such as personal relations and humanity, can also be supported by norms. By drawing on traditions, students legitimize their stance, for or against societal transformation, while trying to connect the past and present with the future.

\section{Justifying societal transformation by reference to norms.}

Students draw upon norms such as to: 'allow free will'; 'strive for human well-being' and 'withhold human-supreme status among animals', as they express their support for using new 
technology for the benefit of human health and well-being. The students either focus on one single type of medical treatment, such as xenotransplantation or gene therapy, or on a more general view, including a variety of possibilities offered by gene technology, particularly for humans:

Life is about having luck. Why not change things (by gene therapy) later if you want to be someone else-why stop someone from that? (Tony)

(The possibility) to change stem cells I think is terrific, since you get another chance. There should be no limits (for curing people). (Veronica)

There is a need for organs (about xenotransplantation), there are so many who are in need. (Charlotte)

The new technologies mentioned here are described as possibilities for the future. Tony argues for agency as he stresses that striving to reach personal desirable out-comes could be facilitated by the new technology. Drawing on the norm of striving for human health, Veronica and Charlotte are likely to agree, as long as it is a health issue. In their view, the new technology provides an opportunity to better care for members of society needing help with their medical condition:

But that's the argument I have for most of these issues: to reduce human suffering and to raise the standard of living and make more happiness in the world. (Oscar)

Oscar also points out the importance of human action for increasing health, but he broadens his view to hold a striving for human well-being in a general sense as a norm for societal practice:

I think its right in every aspect. It is worth sacrificing the life of a pig for the sake of a human. (Carl)

Carl draws on the norm of putting human interests before that of other animals, based on a comparable higher value of a human life, compared with that of a pig. The different values of lives follow a moral order, which is used here to legitimize the use of animals in a new way.

For these students, the use of new technologies provides expectations of a better future since societal practice will be transformed by incorporating biotechnology. They picture biotechnology as a welcome means to achieve desired outcomes. Their norms, which may well be familiar rules for their daily life, are used here to support the acceptance of biotechnology for the development of societal practice. Societal transformation by the exemplified uses of biotechnology here does not seem to evoke any fear of unforeseen risks or need for regulation, among these students. The students express agency by showing that their reflexive monitoring of actions of disembedded societal practice, i.e. experts' development of technologies, are supported by their norms and lead to desired outcomes. Apparently, they trust the experts and that the societal system can be improved by transformation. 
Justifying the prevention of societal transformation by reference to norms. When students expressed a desire to prevent societal transformation, they showed disinterest in the development of new knowledge, fear of losing individuality, an urge to care for and prevent disrespect for animals, as well as a desire to strive for equality between generations and between animals and humans.

One of the students exemplified disinterest in the development of new knowledge and new technology like this:

It is unnecessary/.../In my view, we don't need to develop more things than we already have. (Gabrielle)

She stresses that we should be content with the present societal practice. She seems to ground her view in the norm: 'be satisfied with what you have':

Youshouldn't change just anything because in the end we will all be identical. (Hanna)

The dissatisfaction with our bodies, especially the characteristic parts by which we are judged by others, is here acknowledged as the driving force for genetic modification of everyone, including children. Hanna fears that we will lose our individuality as a result of such action. Her argument against allowing genetic modification of the human body is based on the norm to 'cherish personality' and therefore she wants society to protect the uniqueness in human appearance.

Animals also need to be protected and cared for. For example, animals should not have to suffer:

If I could, I would decide that animals should not have to suffer. No one could feel bad about animals being treated well. (Gabrielle)

Gabrielle has observed that pigs in pig farms suffer and fears that breeding genetically modified pigs for future xenotransplantations might cause even more suffering. Her argument is based on the norm to 'care for animals'. Other ways to express caring for animals are seen in the two following interview excerpts:

Every individual has a right to live. Pigs are also individuals and obviously they have a right to live.(Benny)

No, I think animals, I think breeding of animals shouldn't be allowed, you know, just because we humans want their organs. I think it's wrong. (Veronica)

The students draw on norms to 'respect the right to live' (Benny) and that 'animals and humans should be treated equally' (Veronica). Transformation of society by introducing biotechnology is seen as a threat to norms prescribing that animals should be respected and have rights in society just as humans. Thus, a transformation of societal practice leading to the killing of individuals (in this case, pigs) can never be legitimized. Here, it is not the use of expert knowledge or technology per se that is problematic, just the killing of animals. Transformation through the use of gene technology might be acceptable, but only if the norm 
'respect the right to live' is followed. The risk of not achieving equality in the interaction between pigs and humans justifies the prevention of introducing some uses of gene technology. Prevention of societal transformation justified by 'attempting to achieve equality' is valid for relations between animals and humans, as well as between generations:

Our generations have no more rights than previous generations to make these improvements of our species. (Victor)

According to Victor, equality between generations, i.e. equality in a stretched time-frame moulding history and the future together, should be protected. By referring to equality between generations, historical circumstances are used to argue for the hindrance or control of societal transformation and to reinforce present common practice. Thus, transformation of societal practice cannot be legitimized if it breaks away from the present norms.

For all these students, the new technology is conceived as unnecessary and of little benefi to society. Furthermore, expert knowledge is seen as a societal resource that threatens to exploit animals, nature, and to threaten our attempts to achieve equality. According to the students' observations and reflections, societal practices should not be transformed by new technologies, but rather reproduced by reinforcing present common practices.

The use of new technologies provides a threat, because valued norms may lose their importance if biotechnology is incorporated into societal practice. Although some of these students understand that society can benefit somehow by making use of the described examples, they deny that the anticipated societal transformation could lead to a desired outcome. The imminent societal transformation seems to urge students to call for necessary regulations in the use of technology. In the case of disinterest in new technologies per se, this would mean a total halt in scientific and technological development. Apparently, there is a fear that the social system might be transformed and thereby lose important norms. The students doubtfully express agency by showing that their reflexive monitoring of actions of disembedded societal practice, i.e. experts' development of technologies, implies a clash with familiar norms of specific or general significance. However, students' agency is likely to remain if negotiations for keeping their familiar norms seem to be possible.

\section{Justifying societal transformation by reference to traditions.}

The anticipation of societal change, no matter if it is for better or worse, does reduce the sense of ontological security. One way to counteract this is to reduce the apparent irregularity by finding resemblance with traditions and present practices:

By tradition we have always eaten meat and animals, and so I feel that a development in some way for the use of organs in a new way is a natural step. (Henry)

It's the same thing-we slaughter pigs for food-so I mean, why not slaughter them to get or gans. (Pamela)

These positions are based on the acceptance of slaughtering pigs as being common practice in society. Referring to tradition legitimizes the new practice, which is described as similar to the common practice. Students interpret the two different procedures as being similar, and 
xenotransplantation becomes acceptable based on the historical tradition of slaughtering animals for food. This counteracts the loss of ontological security caused by disembedded practices and their transformation of human action in society. These students extend the organization of beliefs and practices, held by tradition, to include new ones in order to legitimize the societal transformation.

The students' reflexive monitoring of actions, such as routines embedded in tradition, help them to find support for experts' development of technologies leading to desired outcomes. The congruence between students' expectations for development of new technologies that can transform society, and their reasoning to find acceptance for such new technology imply agencyand a trustin experts.

\section{Justifying the prevention of societal transformation by reference to traditions.} The idea of using new technology may be seen to conflict with common practice. In such a case, tradition can be used to legitimize the prevention of introducing new practices in society:

Weare not used to doing like that you know. (Hanna)

But this is different. Wehaven'tbeen doing this for ages. (Veronica)

The above quotes are said with emphasis. The students' perceive the transforming effect of new technologies as detaching future practice from that of the present way of living. The anticipated change of societal practice induces strong reactions from the students. Their anxiety about a possible future transformation of the social system, in discord with familiar practice, is a sign of loss of ontological security. Students draw on tradition when they argue for keeping and reinforcing present practice, thus legitimizing the prevention of societal transformation. A sense of agency can be kept as long as negotiations for keeping familiar routines, organized by traditions, seem to be possible.

\section{Signification by drawing on modalities of domination.}

As these students provide their significations of gene technology, they draw on modalities of Domination, such as knowledge claims and authorities. In so doing, they signify expert knowledge as trustworthy or not trustworthy. By referring to knowledge claims, students express their trust, or the lack of trust, in the basic principles of biotechnology, thus bringing to the fore ideas of risk and monitoring of expert practice. When students refer to authorities, they indicate if they have trust in experts as competent members of society.

\section{Justifying societal transformation by reference to knowledge claims.}

Students can find trust in principles by adhering to different kinds of knowledge claims. By picking up, knowledge claims to ensure safety, as well as support the basic principle for the technology, students can justify the introduction of technology into societal practice.

Here, students seem reassured that procedures are safe if they follow natural laws: 
Since you put in genes, your body will build things, and then, well it has to be better than to put in something that doesn't belong there. It's good for the body since it's the building blocks that were there from the beginning. (Henry)

Although transferring genes from one cell to another may seem unnatural if humans are doing it, since a cell's natural function is used for the production of, for example, proteins, the products can be considered to benatural:

As long as it's produced in a natural way we are reassured that it has been functional and safe in nature for a damn long time since it has been developed by evolution. (Oscar)

The long history of development according to the rules of evolution implies that the process is safe. Furthermore, since evolution is natural, it follows that procedures that apply the natural rules of evolution are safe. By making use of a knowledge claim built on the historical circumstances of evolution, students are able to build an idea of security, concerning the societal use of new technology. The new technology is seen as a resource for transforming societal practice.

These students exemplify how knowledge claims induce trust in a principle. Thereby, they can also find trust in the social system making use of the principle. The ontological security can be further restored by connecting natural phenomena with new technology, thus moderating the notion of potential risks related to the anticipated transformation of societal practice. Knowledge claims that enable reflex- ive monitoring of outcomes, here exemplified by the moderation of potential risks, can be used to justify new practices since they induce trust.

\section{Justifying the prevention of societal transformation by reference to knowledge claims.}

Not all students can find trust and moderate the notion of risks by using knowledge claims. Instead, they advocate knowledge claims that challenge principles of the new technology, and they use knowledge claims to justify limitations or even prevention of the use of new technology. Knowledgeclaims are used to describe athreat:

You are what you are. That's the way it should be. It's unnatural to change/.../Because you change by adding and subtracting, and disturb the order of the events that should have come. (Hanna)

Evolution has not given us the right to make changes in our genetic development. (Victor)

Both these interview excerpts relate to knowledge of what is natural and that human action needs to follow some natural law. The new technologies are threats to naturalness and they do not belong to common practice, and never have. The dichotomy natural/unnatural is used to show that the basic principle is not trustworthy and is a threat to the functional material environment.

The anticipated risks, as a result of unforeseen uncontrollable circumstances, are important arguments against the use of new technologies. This is more explicitly expressed in the following excerpts: 
Suppose you put in a, well genes, for example, in the pancreas for the production of insulin, and it starts to produce enormous amounts of insulin, well that might give negative consequences. (Charlotte)

If you treat everyone (with gene therapy) then the quality of our genes will slowly decrease since there is no natural selection, and in the end maybe we will be totally dependent on this method. (Johnny)

New medical research and medical treatment may result in conditions that are out of control on both personal and population levels. On a population level, the technology may lead to new diseases, and even deterioration of the human species. Knowledge claims seem to enhance the notion of potential risks related to the expected transformation of societal practice. The view of scientific research here is that it breaks away from common practice and what is 'natural'. The natural order is considered to be safe, that is, it is necessary to follow natural laws to have a sense of security. The idea of security cannot be restored, as long as new technology is interpreted as a threat to what is natural.

Knowledge claims are seen as an expression of a reduced ontological security and possibly as a means to reject the expected transformation of societal practice. By reflexive monitoring, the basic principle is judged as less than trustworthy and could lead to undesired outcomes. The new technologies present uncontrollable risks that outweigh the benefits. The students seem worried about risks they claim exist but cannot monitor. They apparently do not trust the principles of expert knowledge and stress that its use is unsafe. This turns these students against the use of expert knowledge and the transformation of the societal structure towards one that comprises unsafe societal practice.

\section{Justifying societal transformation by reference to trust in authorities.}

While the students acknowledge the existence of risks related to the use of new technology, they want the risks controlled. They expect experts to have and to use the necessary competence to handle potential risks:

It's a matter of being cautious and careful, the scientists should be meticulous in their investigations before we start operation on a larger scale. (Oscar)

The risks are very small because they (medical doctors) are educated and know what to do I think. (Benny)

The experts are described as professionals and seen as trustworthy since they are both educated and careful in their practice. It is likely that these students have a sense of ontological security since they do not expect any uncontrollable risks. The students acknowledge distinct roles in society since they consider monitoring and controlling of expert practices to be for experts, 
not for laymen. They find trust in experts by seeing them as authorities of scientific knowledge and disembedded practices. The students' trust in experts counteracts a potential loss of ontological security and their judgment seems to hold that desired outcomes will be attained with acceptable risks.

\section{Justifying the prevention of societal transformation by reference to the lack of trust in authorities.}

It is likely that new practices to some extent create risk scenarios. Students seem to anticipate the future risks on personal as well as population levels.

Authorities have the power to regulate or prevent the future use of new technology that might lead to undesirable outcomes:

But, if they (the scientists) start to fiddle with it (DNA of cells) just to, if they do it for fun; I mean it should be for a purpose, they mustn't sit there and fiddle with cells just to see what happens. (Charlotte)

I mean, if we proceed further (with research on genetically modified organisms) maybe we get rather negative outcomes and face worse things and get worse cells which not only like cancer, but even worse. (Charlotte)

The uncontrollable risks of the new technology outweigh the benefits according to this student. She seems worried about risks she believes exist but no one, not even experts, can monitor. Expert knowledge appears to be unreliable or its use may be unsafe for some reason. This student apparently does not trust experts and expert knowledge to have the ability, or even the intention to control such risks. The lack of trust in experts leaves the students with a reduced ontological security that can lead to the rejection of societal transformation. The anticipated risks turn students against transformation of the societal structure towards one that comprises unsafe societal practice. The fear that science and technology can result in disastrous outcomes is grounded here in the lack of trust in both experts andin disembedded practice.

\section{Signifying Decisions as Enabling or Limiting Human Action in Society}

In this section, we illustrate how the students draw on modalities of Legitimation and Domination in their Signification of decisions as enabling or limiting human action. Legitimation is established by using norms, democracy and laws to justify their view of human-free will and action in society. By referring to the authorities, thestudents express their support for authorities' exertion of power, i.e. Domination, by decisions made through their specific role in society. The students' reasoning implies a conflict regarding the degree oflaymen's participation in decisions about the new technology.

\section{Signification by drawing on modalities oflegitimation.}

The students' dialogue reflects an interesting dimension of trust in the social system as they draw upon norms, democracy and laws to legitimize how decisions on the use of technology should be made. The perspective on 'trust' here includes 'both emotional and cognitive dimensions and to function as a deep assumption underwriting social order' (Lewis \& Weigert, 1985). The results presented in this section can be seen to reflect a possible conflict 
concerning the sensibility of personal decisions considering free will on the one hand and the need for limitation of choice on the other.

\section{Justifications by reference to norms.}

Legitimation of decisions about new technology can be made by referring to norms. In the following example, decisions about the use of gene therapy are discussed:

It's a personal decision, and you should not be forced to do it either. I mean, if you are a u should not have to submit to treatment if you don't want to. (Hanna)

The decision of whether for or against the use of gene therapy should be personal and not forced on a person by any authority. Instead laws should protect free will and personal decisions:

Laws should be made to permit parents to make any decisions concerning their child. (Benny)

We have a right to decide over our own and or our children's bodies and it is implied here that the social system should sanction norms that enable human action based on reflexive monitoring, i.e. agency should be granted to any human being. However, there have to be limits for humanaction:

You can't only see to what the parents want because then they can demand to make just any changes they like to their child. You have to have something else, laws or something like that. (Pamela)

Pamela claims that constraints are needed. She seems to acknowledge the variation of norms as she questions the norms of some fellow members of society. Here, the personal decision, at least when it comes to a parents' responsibility towards their child, is questioned because all parents are not trustworthy. The right to decide over one's children's bodies is contested on the grounds that certain norms need to be sanctioned by laws to limit human behaviour in order to protect them against undesired outcomes. Thus, laws should restrict human actions considered to be unjust. It is expected that what is regarded as a societal norm will beprotected bydemocratic practices.

Trust in the social system is strengthened if it endorses personal agency. Subsequently, if, as a result of new technology, the social system is believed to restrict free will, i.e. personal decisions, trust will be lost and there will be a reluctance to accept imminent transformation of society. However, trust in the social system is also dependent on limitations of personal agency. Laws sanction norms and such limitations on human action induce trust in the social system as it protects norms. In the above context, trust in the social system depends on how the conflict concerning the degree of free will is resolved, which in turn affects the sense of agency.

\section{Justifications by reference to democracy and laws.}

Views about decisions drawing on democracy can actualize the function of laws to regulate the use of new technologies in society. Democratic procedures provide familiar resources to govern the societal system. The laws passed enable as well as constrain human actions in society. 
According to these students, laws that can regulate the use of new technologies should be passed by popular vote in some manageable way:

Evidently, it has to be a democratic decision. It should be what the majority decides, but of course it's difficult so you should have maybe 5 given alternatives to choose from. (Tony)

I think laws about these things should be decided on by popular vote. I don't think the peopleneed to knowbasic genetics but rather seethefuture consequences. (Pamela)

The students suggest the use of both binding and non-binding referendums. The opinion of the majority is given the role of reproducing societal structure, which of course might lead to transformation of societal practice. The statement made by Pamela that people do not need to know basic genetics implies the importance of reflexive monitoring by laymen to consider the potential outcomes of incorporating new technologies into societal practice. Here, students typically relate to laws as rules that legitimize human action by enabling or constraining it. Laws are outcomes of democratic disembedded practice, although they may as well be seen as exertion of power by the authorities. The constraints on minorities, as a result of democratic decisions, appear unproblematic to Tony and Pamela, who apparently trust the democratic principle. Thus, democracy can legitimize any human action and the outcome will be regarded as trustworthy. Democratic decisions induce and sustain trust in the social system, since they enable the agency by reflexive monitoring, here interpreted as the choices given for a decision about biotechnology.

\section{Signification by drawing on domination.}

When it comes to decisions about the use of technology, the students accept the authority's exertion of power on an abstract, general level in society. Such authority is grounded in either political or scientific status and reflects a trust in the societal system. On a concrete level, decisions by medical experts should be preceded by negotiation to include personal knowledge from laymen such as patients.

\section{Justifications by reference to authorities.}

To some students, decisions about the reinforcement or transformation of society appear to be taken by those in authority. Authority is conceived of as being grounded in political or scientific status:

It is the politicians who decide what you are allowed to do within the health care system. (Linda)

This student refers to the present regularized practice in Swedish society when she suggests that the power to decide resides with the political institutions controlling the resources. She does not describe politicians as necessarily being trustworthy, but rather shows an acceptance of politicians exerting power over human action. The description confirms the role of societal facilities such as institutionalized organizations in the structuration of society. The view that officials have specific roles in society controlling the health of our bodies leaves the decisions for future transformation of society to those with political power. The student's acceptanceofthepresent practice indicates a trust in the social system. 
When students justify decisions by referring to authorities with scientific status they state that decisions should be made based on facts, not on opinions:

Scientists and the like, they know everything. Not politicians and those who (have no knowledge), because then it's only opinions you know. Scientists have all the facts. (Veronica)

Medical doctors and maybe patients, they (MDs) consider someone's need, someone who lives a life with a need of a new organ. (Charlotte)

Here, scientists and medical experts are given the role to decide, since they alone have sufficient knowledge. Opinions, although not specified here, are distinguished from knowledge. Subsequently, most members of society are not knowledgeable, at least not when it comes to new technology. Instead, expert knowledge is 'seen as being trustworthy' in contrast to politicians' and laymen's knowledge. Based on this view then, experts should decide about future transformation of societal practice based on expert knowledge. Charlotte's description implies the possibility of mutual agreement when it comes to medical treatments. The focus here is a decision for the benefit of the health of a person, who also happens to be a knowledgeable patient with personal ideas of a desired outcome. The specific situation allows a person-to-person negotiation where a decision can be reached based on mutual understanding, and wherethepatient's agency should be sustained. Here, the distance between knowledgeable laymen and experts may be reduced and trust may be built between real persons. The power to decide over one's own body is reinforced and follows common societal practice.

Trust in political authority is grounded in trust in the social system through which resources can be provided for desired outcomes, which in turn, can be monitored and judged by members of society. When students express trust in expert knowledge by referring to authorities on scientific knowledge, they suggest both trust in the scientific principle and in experts as persons. Furthermore, a stronger trust can be built by negotiating face-to-face and here, as agency is promoted, the building of trust is typically facilitated.

\section{Discussion}

In this section, some methodological aspects will be discussed, followed by a discussion of the results. The discussion of results deals with: (1) how students deal with their loss of ontological security; and (2) how students relate to the agency when reasoning about anticipated changes in societal practice. Each section is followed by a discussion of the pedagogical implications of our results concerning that section. We end our discussion with concluding thoughts where the possibility of sustaining and promoting students' agency in science education is considered.

\section{Discussion ofMethodology}

Since the aims of the study are grounded in an interest to interpret students' notions about societal structures, Giddens (1984) modalities of Legitimation and Domination were used as categories for students' justifications of their significations. Here democracy and laws were chosen as one single modality of Legitimation since laws and democracy are interconnected. However, if any of the students had used laws as a modality of Domination, which is conceivable, the merging of the two could be questioned. The fact that laws can be used as Domination by 
referring to laws as typically made by authorities, without considering social norms, means that future studies in Sweden, as well as in other countries, may need to add to, or extend, the category system. Knowledge claims are constrained to scientific knowledge in this study since the purpose of the study is to describe how students use scientific knowledge, i.e. the disembedded knowledge that can be interpreted as initiating a socioscientific issue.

There are two criteria for such scientific knowledge claims here: first, it has to be possible to interpret them as emanating from expert knowledge, i.e. from disembedded practice; secondly, it has to be used by students as an apparently non-disputable fact. It can be argued that the concept of ontological security is vague and impossible to study. This study does not claim to measure any ontological security but rather, by inference, use it as an attempt to describe problems the students, according to theory, have to cope with when dealing with the different topics. However, the actual experiences the students have are concealed from us.

The impact of what is interpreted as the students' reflexive monitoring and agency is difficult to estimate since the discussions were hypothetical in the sense that the students were not in a situation to decide or take action on any of these issues. However, the students' reasoning could stillberelevantfor a real situation, at least partially, depending on the context and how much later it may occur. Their reasoning is of course more relevant for science education although dependent on the classroom activity.

Finally, the number of students in this study may appear to be limited. However, the analytic approach ensured that saturation was reached, and this helped strengthen the validity of the study. The validity of this study is further strengthened by the presence of similar arguments about gene technology in other studies. For example, see Bates, Lynch, Bevan, and Condit (2005), Barnett, Cooper, and Senior (2007), Chen and Raffan (1999), Gunter et al. (1998), Kolstø et al. (2006), Pearce, Thomas, and Clements (2006), Saucier and Cain (2006), Sadler and Donnelly, (2006) Sadler and Zeidler (2004), Walker and Zeidler (2007), Zeidler, Walker, Ackett, and Simmons (2002), and Zohar and Nemet (2002).

\section{Discussion of Results}

There are many issues that could be discussed from our analysis, however, space constraints have led us to focus on what we regard as the most interesting and worthwhile aspects that we see arising from our analysis: students' ontological security; trust and agency and their promotion in science education. We begin by dealing with students' counteracting their loss of ontological security as new technology is anticipated to result in a transformation of societal practice. We discuss the possibility to reduce loss of ontological security by building trust in authorities in relation to the social structures Legitimation and Domination. We then deal with how these results may be linked to the notion of agency, which is perhaps the most interesting aspect of the ensuing discussion.

Counteracting loss of ontological security and building trust. The anticipated societal change arising from gene technology supports or challenges how students expect the social system to be reproduced or transformed. Modalities of Legitimation are essential for students' building of trust in the societal system and for their notion of participation in societal reproduction or transformation. Modalities of both Legitimation and Domination are important 
for the possibilities of building trust in people representing disembedded practices, i.e. authorities such as experts and politicians.

As shown by other studies, a variety of norms is expected to be found among students (Sadler \& Zeidler, 2004). When the students participating in our study used norms to legitimize their signification of gene technology, they focussed attention on a variety of interesting norms that uncovered potential latent conflicts for science classroom discussions. At the same time, students' expressions of norms and values may change between situations and the negotiability of norms and values could be quite substantial (Macrae, Milne, \& Bodenhausen, 1998), and they can choose which norm is the most important in one specific context and disregard the same norm in another (Zeidler \& Keefer, 2003; Zeidler et al., 2002). Norms are socially enforced rules (Horne, 2009) and a person's subset and ranking of norms depends both on which social group they belong to (Nagda, 2006) and to the social group where the discussions are situated. Therefore, in a discussion about new technology, any conflicts concerning ranking of norms must be considered as negotiable. However, norms sanctioned by moral obligations (Hechter \& Opp, 2001) have to be considered as less negotiable than norms related to social expectations without moral obligations. Still, even though a certain norm can be of high personal importance, it will have a limited impact on ontological security because norms are not routinized (Giddens, 1984). Hence, discussions aiming at resolving conflicts between different norms are likely to have only a limited effect on the counteracting of reduced ontological security among the students.

The threat to norms is less fundamental than that to traditions since societal sanctioning of norms changes more rapidly and because stereotypical expressions for norms are easily overruled in a social context (Macrae et al., 1998). Legitimation by using tradition as a justification has more impact on ontological security than norms. This is because tradition both counteracts fragmentation in time and it is highly routinized (Giddens, 1984). But traditions are not only routinized, they also carry norms and morals that are integrated into a specific practice. By relating to tradition, more meaning is connected to the new practice. The new technology is not seen here as having any interwoven norms or morals itself, and can therefore easily be defined as either belonging to tradition or not. The students in our study used subject content knowledge to interpret how the morals integrated with tradition are in concordance with the application of the new technology. Their ways of reasoning display not only a potential conflict, but also how knowledge and norms can be linked together in different ways. It could be argued whether or not they use knowledge to support traditions or vice versa. Thus knowledge can be used to explain how human action is madelegitimate in a post hoc way. However, according to structuration theory, traditions, and to some extent norms, are habitual rules integrated in embedded practice that can be explained by knowledge without depending on it (Giddens, 1990).

Students who are positive to the new technology use the tradition as a way to bridge the gap between embedded practices (traditions and routinized practices) and disembedded practice (i.e. new technology) (Giddens, 1990). In our study, the students' interpretation is that the new technology can be seen as being embedded in a pre-existing tradition. This was crucial for their stance to use gene technology for the development of societal practice. Hence, the students' reasoning about new technologies and traditions are of high importance for their sense of ontological security and thereby their interpretation of gene technology as a threat or not.

\section{https://repository.uwc.ac.za/}


Since the students drew on norms, democracy and laws to regulate human action in society a conflict regarding agency seemed to emerge. This is a conflict between personal freedom of action, based on personal free will and personal norms, and societally sanctioned actions (Hechter \& Opp, 2001; Horne, 2009). Thus, they had a notion of the discrepancies between embedded practice and disembedded practice, where trust in either people or societal institutions, such as referendums or other democratic legislatures, is at hand. The students showed a trust in the societal system and that the democratic principle will solve conflicts about norms and morals in an acceptable way.

When it came to modalities of the societal structure, the students drew on modalities of Domination, such as knowledge claims and authorities, when discussing future use of gene technology. Their justifications imply an awareness of a risk- benefit conflict, where students focus on trust and physical safety. Scientific knowledge is an important issue here, since students use their knowledge to interpret the safety of the technology, as well as to build trust in basic principles and experts. They moderate their potential loss of ontological security through trust. This is where the discussion of safety is meaningful, i.e. how to escape undesired material outcomes (Giddens, 1990). The students use knowledge claims, related to natural sciences, in support of social norms. This is an important problem to bring to the fore in classroom discussions since knowledge claims usually cannot be used as the cause for social norms in any logical reasoning. Knowledge claims are of course useful to describe material outcomes, which in turn can be judged as desirable or not in relation to norms in a social context.

The students used knowledge claims to strengthen or weaken their trust in the basic principles of the new technology. A trust in the basic principle comes with a sense of security. Students who embrace the new technology are the ones who trust the basic principle, experts and their knowledge. However, students who want to prevent the use of the new technology showed no trust in the basic principle. The latter group of students could be described as the target for the PUS and STS movements (Irwin, 2001; Irwin \& Wynne, 1996) in their quest for education for a 'knowledge society'.

When drawing on authorities, the students classified experts in terms of perceived competence. Here, judgements about competencies, and perhaps even the intentions among experts, became guesswork. The students who desire a change in the societal practice by the new technology felt no need for the monitoring of experts. Similarly to laymen, students are seldom in a position to monitor experts' activities, and so they just have to trust them and/or the capacity of the social system to control the experts. The students with little trust in experts and disembedded practices were anxious about the possibility of disastrous outcomes. Their lack of trust in disembedded practices may lead to less trust in the societal system and loss of agency. The students with a low ontological security, as expressed by doubts and fear of uncontrolled risks, recognise experts as authorities with power (Domination). However, they do not trust experts and so they seek in vain to monitor experts' practice to counteract theirloss ofontological security.

Pedagogical implications regarding students' ontological security and trust. In a discussion where conflicting views about traditions are disclosed, the loss of a sense of 
security is likely to be an important issue. By strengthening such discussions, where both emotional and intellectual aspects can be used to understand the conflict they constitute, possibilities for participation in future societal discussions have a good possibility of being developed (Sadler \& Zeidler, 2005a, 2005b). Important directions for such discussions are about the search for intelligible relations between modalities of Legitimation and Domination. This could be done by raising the awareness of norms as socially constructed and that they, as such, can becomeless understandable if scientific knowledge claims (Domination) are used to 'prove' that a norm (Legitimation)isright.

To reach an understanding of the conflict concerning Legitimation, a discussion needs, at least initially, to be limited to just Legitimation issues and to acknowledge laymen's knowledge. Discussions based on embedded practice facilitate personal interaction where trust can be built in people-not in abstract principles or disembedded practices. This can be of vital importance for future opportunities to build trust and to counteract loss of ontological security. Such a discussion concerning Legitimation issues can bridge the gap between embedded and disembedded practice. However, this opportunity may be jeopardized if, say, two opposing student groups jump to conclusions drawn only from disembedded practices such as either scientific knowledge or legislatures.

In the classroom, risks can be addressed by dealing sceptically with the knowledge claims of basic principles and expert practices (Domination). Science education can also deal with risks as a matter of Legitimation by bringing more attention to the capacity of the social system to control the development and use of disembedded practice. An integrated classroom discussion could arguably be more beneficial for the students who need to counteract their low ontological security by creating a focus on scientificknowledgeclaims that are not given priority over Legitimation and immaterial outcomes. If it is made acceptable that norms and traditions also can be the basis for signification, then knowledge claims and experts' knowledge, or their lack of it, is not the issue. Rather, a discussion for counteracting loss of ontological security and building trust should concern Legitimation. This interpretation finds support in the findings where students call for legislative regulations of experts' actions.

The problem of not addressing such aspects in science education has already been identified (Kolstø, 2001b; Sadler \& Zeidler, 2005a; Zeidler, Sadler, Applebaum, \& Callahan, 2009). The students' different stances concerning Domination in this study, suggest that a classroom discussion focusing on physical safety and knowledge claims might bring attention to incorrect-correct or sufficient-insufficient knowledge and ignore other aspects, such as norms, morals and emotions. The emphasis on Domination may give a structural perspective to clarify parts of a classroom discussion. In a discussion, knowledge claims could be used to build trust in basic principles and to feel physically safe, but if knowledge claims instead are used for the purpose of supporting or defying norms and values, then the conflict instead needs to be understood within the realms of Legitimation. Legitimation and Domination are not mutually exclusive (Giddens, 1984), but if there is more than one discussion, i.e. a discussion about one societal structure implicitly framed by another, then a constructive dialogue can be hampered, thus negatively impeding development of a functional science literacy. Such framing can be the result of science education in classrooms that do not openly permit aspects other than scientific knowledge (Driver et al., 2000; Sadler \& Zeidler, 2005a; Zeidler \& Sadler, 2008), as in traditional science education. 
Promoting agency through reflexive monitoring. Agency through reflexive monitoring is implied when students state that their norms are congruent with those of experts and experts' practice. Agency is also implied through students' belief that a transformation of societal practice is likely to lead to desired outcomes. However, reflexive monitoring using personal investment in the understanding and appraisal of the new technology might still be absent (May \& Finch, 2009). Thus, such expression of agency can be deceptive since the trust in experts does not call for any need to participate personally. This implies the need for science education that stimulates scepticism of scientific knowledge (Kolstø, 2001b; Kolstø et al., 2006; Zeidler \& Sadler, 2010).

Students who express a desire to prevent transformation of societal practice recognize a conflict between their norms and that of experts. They have little trust in the ability of the societal system to prevent the anticipated transformation of practice and subsequently fail to express agency in the interview situation. These students would benefit from education for a 'critical society' since they are searching for trust in the system; focusing on modalities of Legitimation, rather than in experts. Science education could help students to place their trust in the social system by providing students with chances to invest actively in their understanding of the function of Legitimation in relation to human action and changing social practice. Furthermore, such knowledge could broaden their opportunities for reflexive monitoring and in turn help them to gain a sense of agency.

The students in our study pointed out that laymen do not need to know much about genetics and the basic principles of gene technology to make decisions about desired changes in societal practice. So, it seems that students may generally consider laymen as knowledgeable persons who can participate in Legitimation without much scientific knowledge. This is in line with the notion of a 'Critical society' (Brennan, 2008; Kalantzis, 2006; Szkudlarek, 2007). However, students also brought attention to a conflict between personal desires and laws. In classroom discussions, such conflicts are likely to promote students' engagement in SSIs, and the development of agency for democratic participation in decisions for the reproduction or transformation of societal practice. Such discussions are well suited for SSIs since they include both personal positions grounded in embedded practice and general, political positions grounded in students' understanding of disembedded practice and the societal system. Here the issue seems to be able to define grounds for Legitimation in both embedded and disembedded practice. By understanding how the interaction between different grounds of Legitimation can lead to new regulations and laws in society, students can improve their reflexive monitoring, whereby their sense of agency will be facilitated. By negotiating moral as well as amoral norms in different contexts as they discuss interactions between norms on the one hand and democracy and laws on the other, they get an opportunity to understand the workings of democratic legislature and to build trust in the societal system.

Decisions that were justified by modalities of Domination, such as expert knowledge, were students' expression of trust in experts and in the system, where the power of authorities is acknowledged and accepted. According to some of the students, authorities such as experts in gene technology and medicine exert their power when given a regulatory role. Their trust in experts, built on appreciation of what is expected to be their knowledge may well be a result of science education and medial influence sustaining ontological security. The 
downside is that such trust can prevent the sense of agency. Students drawing on modalities of Domination describe disembedded practices, where authorities have specific roles and laymen have to trust them for some reason. The students who accept the decisions made by authorities also trust them. They do this either on grounds such as expert knowledge or on democratic political grounds. Here, the conflicts between students' positions puts politics and expert knowledge in opposition to each other, claiming that political views are not as 'reliable' as expert knowledge. This, in turn, puts laymen's participation in decisions into question because laymen are as knowledgeable as politicians whenit comes to, say, genetechnology.

Pedagogical implications regarding students' agency. Science education that promotes the understanding of SSIs as multifaceted problems, which need to be defined, has the potential to help students to develop reflexive monitoring of social practice, which covers more than just material outcomes. One possibility is to describe and make use of both of the societal structures Legitimation and Domination. For example, the 'fear' of potential degeneration of humans, as indicated by a student in our study, is a material safety risk and a matter of resources (Domination), whereas the risk of losing the norm that celebrates human uniqueness is an immaterial risk and an issue concerning rules (Legitimation). Each could be addressed and appreciated separately to build an insightful understanding of how they depend on the interaction between societal structures and human action. Such differentiation is likely to help students in their reflexive monitoring, thus supporting their agency by clarifying which societal structure an outcome of human action is typically dependent on. Students' agency can be supported due to the fact that interaction with a specific societal structure makes reflexive monitoring of an issue more intelligible. Thus, science education can support students' development of agency through better scientific knowledge and through knowledge about how social practice depends on societal structures.

A developed knowledge of the social system applied in a context can also bring awareness of intentions in a negotiation. This could increase students' understanding of why their perceptions of new technology as a threat can make them prone to turn to regulation through Domination by calling for legislatures and political authorities to save their socially embedded norms and practices and to compensate for loss of ontological security. Knowledge about the social system might also be of importance to students perceiving new technology as a promise to see beyond material benefits and instead include reflexive monitoring of social norms and how they interact with human action in society.

Concluding thoughts. The modalities of Domination are the enactments of traditional science education, where students are envisaged as building trust in both basic principles and in experts (Irwin, 2001; Styles, 2002). Unfortunately the modalities of Domination have been confused with those of Legitimation, a problem apparent in the description of the so-called collateral learning (Aikenhead \& Jegede, 1999). It cannot be denied that with specific scientific knowledge, outcomes on a material level can be scrutinized and found to be desirable or not. However, the issue raised here is one of science literacy as an integral aim of science education for a 'knowledge society' 
characterized by Roberts' (2008) vision I or II modelling of scientific literacy. In contrast to traditional scientific education, a vision II based science education has the potential to support reflexive monitoring. Although vision II may be only for strictly material outcomes, it does support the generation of agency when dealing with issues concerning societal use of scientific knowledge. From our study, we would argue that students need knowledge about specific basic principles in such a way that it is useful in given contexts. The students in this study use, for example, evolution, natural selection and natural/unnatural as principles for their judgments, but their understanding of these terms does not seem to allow them to understand the full meaning in these contexts. Here the full-fledged use of SSIs in science education can give further support to students' development of understanding for the use of knowledge in a context by including aspects other than scientific knowledge. This would promote reflexive monitoring of material as well as immaterial outcomes.

In science education, students can learn to trust the basic principles of expert knowledge, as well as to trust experts. However, if experts are seen as authorities, not only in their scientific field, but also when it comes to norms (or that norms are not an issue), there will be little possibility of a sense of agency. Such reliance on experts corroborates scepticism of scientific knowledge claims and experts intentions, and preserves naive attitudes towards immaterial outcomes of societal transformation.

This could be counteracted in science education by promoting an awareness of how permissive laws (Legitimation) through Domination would not only mean giving experts freedom to carry on their work for technical development, but also to change social norms through disembedded practices without democratic discussions. Although trust in authorities will facilitate regaining a sense of ontological security, it will be at the expense of agency and the participation in societal transformation or reproduction.

Students signifying new technology as a threat seem unlikely to find trust in experts through basic principles of expert knowledge. For them, modalities of Domination, such as scientific knowledge, do not counteract their loss of ontological security or help to build trust. Instead, they need to learn to understand how to use face-to-face interactions for building trust through Legitimation, instead of Domination. Trust in the system together with a sense of ability of reflexive monitoring of immaterial outcomes can counteract these students' loss of ontological security as they see the opportunity to negotiate their threatened norms and traditions. Science education debates (Kolstø, 2001b; Zeidler et al., 2009), or even better, the meeting between students and politicians for authentic discussions about SSIs (Jimené z-Aleixandre, 2002), provide excellent possibilities for development of students' ability to participate in societal discussions, to build trust as well as to gain a sense of agency. An important subject for discussion in science education then would be the discrepancy between embedded and 
disembedded practice. This is because sceptical trust in the societal system and in disembedded expert practice can be built together with specific knowledge for reflexive monitoring of the support for the sense of agency concerning SSIs. However, since trust, being of importance for ontological security, leads to Domination, it needs to be balanced by supporting the development of a sense of agency.

We would argue that our discussion provides the basis for enhancing the kind of progressive development of students' ability to participate in societal discussions that must be embedded in a modern democracy. Furthermore, perhaps most importantly, such engagement has the distinct potential of being able to significantly contribute to building trust, as well as to gain a sense of agency as part of a modern science education setting.

\section{Acknowledgements}

The authors are grateful to the students who participated and shared their time to make this study possible. Thanks are also due to Anne Linder and Dr Anne-Mari Folkesson for valuable discussions and careful commenting on text and interpretations, and to the two anonymous reviewers for their insightful comments and valuable suggestions, which helped us to improve the paper. The research was financially supported by Faculty of Natural Science and Technology and The Board of Teacher Training and Educational Research at Linnaeus University, and the Division for Physics Education Research, Uppsala University. 


\section{References}

Aikenhead, G.S. (2006). Science education for everyday life: Evidence-based practice. New York, NY: Teachers College Press.

Aikenhead, G.S. (2007). Expanding the research agenda for scientific literacy. Paper presented at the Linnaeus tercentenary 2007 symposium 'Promoting scientific literacy: Science Education Research in Transaction', Uppsala University, Uppsala, Sweden.

Aikenhead, G.S., \& Jegede, O. (1999). Cross-cultural science education: A cognitive explanation to a cultural phenomenon. Journal of Research in Science Teaching, 36(3), 269-287.

Barnett, J., Cooper, H., \& Senior, V. (2007). Belief in public efficacy, trust, and attitudes toward modern genetic science. Risk Analysis, 27(4), 921 933.

Bates, B.R., Lynch, J.A., Bevan, J.L., \& Condit, C.M. (2005). Warranted concerns, warranted outlooks: A focus group study of public understandings of genetic research. Social Science \& Medicine, 6o, 331-344.

Bauer, M.W. (2005). Public perception and mass media in the biotechnology controversy. InternationalJournal of Public Opinion Research, 17(1), 5-22.

Brennan, J. (2008). Higher education and social change. Higher Education, 56, 381 393. Calderhead, J. (1981). Stimulated recall: A method for research on teaching. British Journal of Educational Psychology, 51, 211-217.

Chen, S.Y., \& Raffan, J. (1999). Biotechnology: Students knowledge and attitude in the UK and Taiwan. Journal of Biological Education, 34(1), 17-23.

Christoph, I., Bruhn, M., \& Roosen, J. (2008). Knowledge, attitudes towards and acceptability of genetic modification in Germany. Appetite, 51, 58-68.

Cobern, W.W. (1996). World view theory and conceptual change. Science Education, 8o(5), 579-610.

Costa, V.B. (1995). When science is another world. Science Education, 79(3), 313 333.

Dawson, V.M. (2007). An exploration of high school (12 - 17 year old) students' understandings of attitudes towards biotechnology processes. Research in Science Education, 37, 59-73.

Driver, R., Newton, P., \& Osborne, J. (2000). Establishing the norms of scientific argumentation in classrooms. Science Education, 84, 287-312.

Fensham, P.J. (1988). Familiar but different: Some dilemmas and new directions in science education. In P.J. Fensham (Ed.), Developments and dilemmas in science education (pp. 1-26). New York, NY: Falmer Press.

Fowler, S.R., Zeidler, D.L., \& Sadler, T.D. (2009). Moral sensitivity in the context of socioscientific issues in high school science students. International Journal of Science Education, 31(2), 279-296.

Gaskell, J.P. (1982). Science, technology and society: Issues for science teachers. Studies in Science Education, 9, 33-36.

Gaskell, J.P. (1992). Authentic science and school science. International Journal of Science Education, 14(3), 265-272.

Giddens, A. (1984). The constitution of society: Outline of the theory of structuration. Cambridge: Polity Press.

Giddens, A. (1990). The consequences ofmodernity. Cambridge: Polity Press. 
Gunter, B., Kinderlerer, J., \& Beyleveld, D. (1998). Teenagers and biotechnology: A survey of understanding and opinion in Britain. Studies in Science Education, 32, 81-112.

Hechter, M., \& Opp, K.-D. (2001). What we have learned about the emergence of social norms? Social norms (pp. 394 - 415). Berkeley, CA: University of California Press.

Heijs, W.J.M., Midden, C.J.H., \& Drabbe, R.A.J. (1993). Biotechnology, attitudes and influence factors. Eindhoven: Eindhoven University of Technology.

Horne, C. (2009). A social norms approach to legitimacy. American Behavioral Scientist, 53(3), 400-415.

Irwin, A. (2001). Constructing the scientific citizen: Science and democracy in the biosciences. Public Understanding of Science, 10(1), 1-18.

Irwin, A., \& Wynne, B. (1996). Misunderstanding science? The public reconstruction of science andtechnology. Cambridge: Cambridge University Press.

Jimené z-Aleixandre, M.-P. (2002). Knowledge producers or knowledge consumers? Argumentation and decision making about environmental management. International Journal of Science Education, 24(11), 1171-1190.

Kalantzis, M. (2006). Elements of a science of education. Australian Educational Researcher, 33(2), 15-42.

Kelley, J. (1995). Public perceptions of genetic engineering: Australia, 1994. Canberra: Biotechnology Section, Australian Department of Industry, Science and Technology.

Klosterman, M.L., \& Sadler, T.D. (2010). Multi-level assessment of scientific content knowledge gains associated with socioscientific issues-based instruction. International Journal of Science Education, 32(8), 1017-1043.

Knight, A. (2007). Intervening effects of knowledge, morality, trust, and benefits on support for animal and plant biotechnology applications. Risk Analysis, 27(6), $1553-1563$.

Kolstø, S.D. (2000). Consensus projects: Teaching science for citizenship. International Journal of Science Education, 22(6), 645-664.

Kolstø, S.D. (2001a). Scientific literacy for citizenship: Tools for dealing with the science dimension of controversial socioscientific issues. Science Education, 85, $291-310$.

Kolstø, S.D. (2001b). To trust or not to trust, .. ‘-pupils' ways of judging information encountered in a socioscientific issue. International Journal of Science Education, 23, 877-901.

Kolstø, S.D., Bungum, G., Arnesen, E., Kristensen, T., Mathiassen, K., Mestad, I., .. . Ulvik, M. (2006). Science students' criticl exaination of scientific information related to socioscientific issues. Science Education, 90, 632-655.

Levinson, R. (2010). Science education and democratic participation: An uneasy congruence? StudiesinScienceEducation, 46(1), 69-119.

Levitt, M. (2003). Public consultation in bioethics. What's the point of asking the public when they have neither scientific nor ethical expertise. Health Care Analysis, 11(1), 15-25.

Lewis, J.D., \& Weigert, A. (1985). Trust as a social reality. Social Forces, 63(4), 967 985 . 
Lindahl, M.G. (2009). Ethics or morals-Understanding students' values related to genetic tests on humans. Science andEducation, 18, 1285-1312.

Lindahl, M.G. (2010). Of pigs and men-Understanding students' reasoning about the use of pigs as donors for xenotransplantation. Science \& Education, 19(9), 867-894.

Macrae, C.N., Milne, A.B., \& Bodenhausen, G.V. (1998). Saying no to unwanted thoughts: Self-focus and the regulation of mental life. Journal of Personality and Social Psychology, 74(3), 578-589.

May, C., \& Finch, T. (2009). Implementing, embedding, and integrating practices: An outline of normalization process theory. Sociology, 43, 535 554 .

McWilliam, W., \& Lee, A. (2006). The problem of 'the problem with educational research'. The AustralianEducational Researcher, 33(1), 43-60.

Nagda, B.R.A. (2006). Breaking barriers, crossing borders, building bridges: Communication processes in intergroup dialogues. Journal of Social Issues, 62(3), 553-576.

Nelkin, D. (2001). Beyond risk: Reporting about genetics in the post-Asilomar press. Perspectives in Biology and Medicine, 44(2), 199-207.

Norris, S.P., \& Phillips, L.M. (2003). How literacy in its fundamental sense is central to scientific literacy. Science Education, 87, 224-240.

Pearce, C.E., Thomas, A.P.M., \& Clements, D.A.V. (2006). The ethics of xenotransplantation: A survey of student attitudes. Xenotransplantation, 13, $253-257$.

Phelan, P., Davidson, A.L., \& Cao, H.T. (1991). Students' multiple worlds: Negotiating the boundaries of family, peer and school cultures. Anthropology \& Education Quarterly, 22, 224-250.

Ratcliffe, M. (1996). Adolescent decision-making, by individuals and groups, about science-related societal issues. In G. Welford, J. Osborne, \& P. Scott (Eds.), Research in science education in Europe: Current issues and themes (pp. 126 140). London: Falmer Press.

Roberts, D.A. (2008). Scientific literacy/science literacy. In S.K. Abell \& N.G. Lederman (Eds.), Handbook of research on science education (pp. $729-780$ ). New York, NY: Routledge.

Sadler, T.D. (2004). Moral sensitivity and its contribution to resolution of socio-scientific issues. Journal of Moral Education, 33(3), 339-358.

Sadler, T.D., \& Donnelly, L.A. (2006). Socioscientific argumentation: The effects of content knowledge and morality. International Journal of Science Education, 28(12), 1463-1488.

Sadler, T.D., \& Fowler, S.R. (2006). A threshold model of content knowledge transfer for socio-scientific argumentation. Science Education, 90, 986-1004.

Sadler, T.D., \& Zeidler, D.L. (2004). The morality of socioscientific issues: Construal and resolution of genetic engineering dilemmas. Science Education, $88,4-27$.

Sadler, T.D., \& Zeidler, D.L. (2005a). The significance of content knowledge for informal reasoning regarding socioscientific issues: Applying genetics knowledge to genetic engineering issues. ScienceEducation, 89,71-93. 
Sadler, T.D., \& Zeidler, D.L. (2005b). Patterns of informal reasoning in the context of socioscientific decision-making. Journal of Research in Science Teaching, 41(1), $112-138$.

Saucier, D.A., \& Cain, M.E. (2006). The foundations of attitudes about animal research. Ethics \& Behavior, 16(2), 117-133.

Schwartz, S.H., \& Bilsky, W. (1987). Toward a universal psychological structrure of human values. Journal of Personality and Social Psychology, 53(3), 550-562.

Solomon, J. (1992). The classroom discussion of STS issues: Public understanding of science in the making. In R.E. Yager (Ed.), The status of science-technology-society reform efforts around the world: ICASE Yearbook 1992 (pp. 67 -80). Hong Kong: International Council of Associations for Science Education.

Solomon, J. (1993). Teaching science, technology \& society. Philadelphia, CA: Open University Press.

Styles, M.L.B. (2002). Using education as a public relations tool for biotechnology. Plant Cell, Tissue and Organ Culture, 70, 23-26.

Szkudlarek, T. (2007). Empty signifiers, education and politics. Studies in Philosophy and Education, 26, 237-252.

Tal, T., \& Kedmi, Y. (2006). Teaching socioscientific issues: Classroom culture and students performances. Cultural Studies in Science Education, 1, 615-644.

Taylor, P., Lee, S.H., \& Tal, T. (2006). Toward socio-scientific participation: Changing culture in the science classroom and much more-Setting the stage. Cultural Studies of Science Education, 1, 645-656.

Walker, K.A., \& Zeidler, D.L. (2007). Promoting discourse about socioscientific issues through scaffolded inquiry. International Journal of Science Education, 29(11), 1387-1410.

Zeidler, D.L., \& Keefer, M. (2003). The role of moral reasoning and the status of socioscientific issues in science education: Philosophical, psychological and pedagogical considerations. In D.L. Zeidler (Ed.), The role of moral reasoning on socioscientific issues and discourse in science education (pp. 7-38). The Netherlands: Kluwer Academic Press.

Zeidler, D.L., Lederman, N.G., \& Taylor, S.C. (1992). Fallacies and student discourse: Conceptualizing the role of critical thinking in science education. Science Education, 75(4), 437-450.

Zeidler, D.L., \& Sadler, T.D. (2008). The role of moral reasoning in argumentation: Conscience, character and care. In S. Erduran \& M.P. Jimenez-Aleixandre (Eds.), Argumentation in science education: Perspectives from classroom-based research (pp. 201-216). The Netherlands: Springer Press.

Zeidler, D.L., \& Sadler, T.D. (2010). An inclusive view of scientific literacy: Core issues and future directions of socioscientific reasoning. In C. Linder, L. Ö stman, D.A. Roberts, P.O. Wickman, G. Erickson, \& A. MacKinnon (Eds.), Exploring the landscape of scientific literacy (pp. 176 - 192). New York, NY: Routledge.

Zeidler, D.L., Sadler, T.D., Applebaum, S., \& Callahan, B.E. (2009). Advancing reflective judgement through socioscientific issues. Journal of Research in Science Teaching, 46(1), 74-101. 
Zeidler, D.L., Sadler, T.D., Simmons, M.L., \& Howes, E.V. (2005). Beyond STS: A research-based framework for socioscientific issues education. Science Education, 89, 357-377.

Zeidler, D.L., Walker, K.A., Ackett, W.A., \& Simmons, M.L. (2002). Tangled up in views: Beliefs in the nature of science and responses to socioscientific dilemmas. Science Education, 86, 343-367.

Zohar, A., \& Nemet, F. (2002). Fostering students knowledge and argumentation skills through dilemmas in human genetics. Journal of Research in Science Teaching, 39(1), 35-62. 